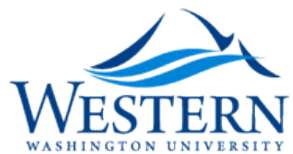

Western Washington University

Western CEDAR

Summer 2000

\title{
Love and Sex in Mario Vargas Llosa's 'Quien mato a Palomino Molero?'
}

Brent Carbajal

Western Washington University, Brent.Carbajal@wwu.edu

Follow this and additional works at: https://cedar.wwu.edu/mcl_facpubs

Part of the Latin American Languages and Societies Commons, and the Latin American Literature Commons

\section{Recommended Citation}

Carbajal, Brent, "Love and Sex in Mario Vargas Llosa's 'Quien mato a Palomino Molero?"' (2000). Modern \& Classical Languages. 49. https://cedar.wwu.edu/mcl_facpubs/49

This Article is brought to you for free and open access by the Humanities at Western CEDAR. It has been accepted for inclusion in Modern \& Classical Languages by an authorized administrator of Western CEDAR. For more information, please contact westerncedar@wwu.edu. 


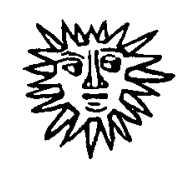

LOVE AND SEX IN MARIO VARGAS LLOSA'S ¿QUIÉN MATÓ A PALOMINO MOLERO?

\author{
BRENT J. CARBAJAL \\ Western Washington University
}

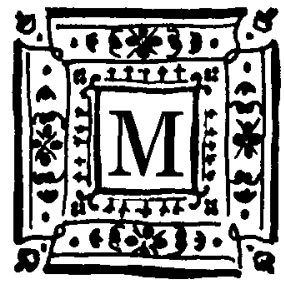

ARIO Vargas LIosa's murder mystery ¿Quién mató a Palomino Molero?, while certainly as entertaining an example of its genre as one would expect from an author of such universally acknowledged narrative skill, ${ }^{1}$ is ultimately less a tale of complicated sleuthing than it is a commentary on collective corruption, social injustice and base human nature. Against a sharply defined backdrop of the class system in his native Peru, Vargas Llosa registers in this novel the socio-political reality that oppresses the individual by limiting his opportunities, both personal and professional, and dooming to failure any attempt to escape the mandates of systemic social stratification. The author achieves his bleak portrayal of Peruvian society in a number of ways, but primary among them is his presentation of the theme of forbidden love and his use of coarse sexual imagery and counterpoint. It is through thematic considerations associated with problematic love and sex that Vargas Llosa creates a scenario in ¿Quién mató a Palomino Molero? that not only admits the occurrence of the young pilot's gruesome murder, but that also

${ }^{1}$ For an excellent overview and assessment of Vargas Llosa's work up to $L a$ guerra del fin del mundo, see Gerdes. 
makes it an almost logical consequence and conclusion to his "illicit" love affair.

While a detailed summary of the plot of the novel is not required here, a brief overview of the particulars of the crime and the two detectives' investigation is helpful in establishing certain points for further analysis and consideration. The novel begins with the discovery of the mutilated cadaver of a young air force pilot. As Lieutenant Silva and his aide Lituma set out to investigate the crime, they uncover a great deal of evidence, rather quickly, that indicates the possible existence of a military cover-up designed to protect powerful leaders. Eventually, the two detectives gather enough information to implicate Colonel Mindreau, the uncooperative and seemingly omnipotent commander of the air base. Faced with the prospect of his crime being discovered by the civil authorities, (an embarrassment in and of itself due to his sense of invincibility on base and feeling of superiority over his civilian counterparts), Mindreau kills his daughter and commits suicide. In a confession given to the detectives prior to his putting a gun to his head, Mindreau states that he ordered Palomino's murder in order to protect his daughter Alicia from the consequences of her amorous relationship with Palomino, a lowly mestizo. He had sent one of his subordinates, Lieutenant Dufó, to kill Palomino and thus claims no responsibility for the horrific nature of the torture that preceded the murder. Alicia had previously confided to the detectives that her father abused her and that he had for many years engaged in relations with her, but Colonel Mindreau dismisses this in his confession as being yet another example of his daughter's delusions brought about by her mental illness. The two detectives are "rewarded" for their successful investigation by being transferred to outlying areas by an ambiguous administrative authority, and by the community doubting the detectives' conclusions, the "common folk" preferring instead to hold to a conspiracy theory involving foreign powers. This reluctance on the part of the public to accept the detective's explanation of the crime and the deaths of Mindreau and his daughter create an open ending to the novel which clouds any definitive answer to the question posed by the title of the book.

Parallel to the crime investigation is the development of Lieutenant Silva's quest for the sexual attention and favors of Dona Adriana, the married owner of a restaurant at which Silva and Lituma frequently dine. While Silva's lust for Adriana is a sub-plot in the novel, it at times seems to overtake the crime investigation in importance as Silva's desire to possess the woman pervades his moti- 
vation and thought process. In fact, it is as if Silva is obsessed with Adriana to the extent that his work is secondary. During a trip to a nearby city to gather information for the investigation, Silva dedicates more conversation to trivialities and to Adriana than he does to the murder investigation:

desde que entraron a la choza de Doña Lupe era como si al Teniente Silva se le hubiera eclipsado la curiosidad por Palomino Molero. Toda la comida no había hecho otra cosa que hablar del nombre de Amotape, o, claro está, de Doña Adriana. ${ }^{2}$

Like the less than satisfying outcome of the criminal investigation, however, Silva is ultimately not rewarded with Adriana's virtue but rather summarily dismissed by the woman while sustaining a devastating blow to his masculinity or "machismo."

The ambiguous ending to the crime investigation and the apparent distraction posed by the sub-plot have caused ¿Quién mató a Palomino Molero? to be received less than favorably by some critics. Julio Ortega, for example, states:

¿Quién mató a Palomino Molero? utiliza un dialecto truculento, y suma al crimen un incesto, un asesinato y un suicidio, [pero] termina siendo un relato excesivamente tenue. ... Si la imposibilidad de encontrar la verdad en una sociedad corrompida por el poder y estupidizada por los prejuicios es aquí el problema central, ese problema ha sido trivializado por su planteamiento. $\quad(975-76)^{3}$

Antonio Cornejo Polar criticizes the novel for its open ending as well as its simplicity (283), and others claim that the 1986 novel is a disappointment when compared to earlier works like La casa verde (1966). ${ }^{4}$ This criticism misses the mark, however, and ignores the subtle importance of ambiguity in this work. Critic Arnold M. Penuel, in fact, disagrees with Ortega and Cornejo Polar and says that "Vargas Llosa's ambiguities serve to widen the reader's perceptions and sympathies within the framework of the social relations he dramatizes" $(945) .{ }^{5}$ The

${ }^{2}$ This quote is found on pages $85-86$ of the novel. All subsequent quotations will be noted parenthetically in the text.

${ }^{3}$ Ortega also claims in this article that $i$ Quien mató a Palomino Molero? is the least interesting novel Vargas Llosa has written (975).

${ }^{4}$ See Béjar for a brief summary of negative criticism of the novel.

${ }^{5}$ Penuel also discusses his idea that Vargas Llosa employs a "perspectivism" that enables him to exploit as many levels of reality as he can (944-46). 
narrative counterpoint of base sexual behavior and the theme of forbidden love that characterize ¿Quién mató a Palomino Moleno? also evoke the ambiguity mentioned by Penuel and facilitate Vargas Llosa's scrutiny of multifaceted reality. As mentioned above, love and sex serve as vehicles with which the author illuminates Peruvian social ills as well as the difficulty faced by the individual in search of an answer and response to collective social corruption.

To begin to examine the theme of love, (or forbidden love), in ¿Quién mató a Palomino Molero?, it is instructive to evaluate the nature of amorous relationships found in the novel. Perhaps most importantly, Palomino Molero was brutally murdered for daring to love a woman from the upper class. Palomino himself was aware of the danger his liaison with Alicia represented and confided to the bartender Moisés, "estoy enamorado, Moisés, y mi amor es imposible" (23). Society had dictated that a "cholo," or man of mixed race, could not be romantically involved with a white woman of the military ruling class, and Palomino was symbolically castrated and killed for having challenged that rule. Coronel Mindreau's amorous and incestuous relationship with his daughter brings them nothing but pain and their own eventual destruction. In describing her father's love for her, Alicia states:

El amor no tiene fronteras, dice. El mundo no entendería. La sangre llama a la sangre, dice. El amor es el amor, un huayaco que arrastra todo. Cuando dice eso, cuando hace esas cosas, cuando llora y me pide perdón, lo odio.

The shame and social embarrassment associated with his relationship with his daughter, and the possibility of its being divulged in public, would have been too much for Mindreau, and he unhappily saw no alternative other than to murder his daughter and then commit suicide himself. In a sense, this is another case of forbidden love.

A third example of this theme in the novel is really more a case of "thwarted lust." Lieutenant Silva's desire to consummate his "love" for doña Adriana results in catastrophe for him as his manhood, his "machismo," is destroyed by Adriana's rejection. After stating his intention to "tirarme de una vez a esa gorda de mierda" (171), Silva's attempted rape of the woman is comically and definitively never realized as the result of her bold challenge:

¿Tan chiquita la tienes, papacito? Anda, anda, apúrate, bájate el pantalón y muéstramela. Ven, viólame de una vez. Muéstrame lo macho que eres, 
papacito. Cáchame cinco veces seguidas, que es lo que hace mi marido cada noche.

(184)

Silva is reduced to a mere shadow of himself after this exchange, and he realizes that his "love" for Adriana is, and always will be, impossible.

Other, perhaps secondary, love relationships in the novel include those between the prostitutes and most of the male characters, the unlucky affair between Lieutenant Dufó and Alicia, and the marriage between Matías and Adriana. The nature of the relationships between the prostitutes and the male characters requires little explanation here; it is sufficient to recognize that "true love" is not a factor. ${ }^{6}$ Dufó's love for Alicia was made forbidden by jealousy and possessiveness on the part of Mindreau and the former's dedication to following orders. Once again, military mandate forbade this love affair. Finally, and typically ignored by critics, the love and marital relationship between Adriana and Matías is at least affected by society, if not weakened, by the fact that their working-class lives dictate that she spend the day working in the restaurant while he sleeps and that he spend the night at sea while she goes to bed alone. Theirs is indeed a healthy relationship, but their complete happiness is, to a certain extent, forbidden by their economic reality.

While Lituma doesn't have a love affair with which society interferes, he is profoundly affected by what he witnesses in relation to love. As a subordinate to Silva, he has no choice but to participate in sordid adventures with his boss and to assist him whenever possible in his attempt to rape Adriana. He is amused by Silva's lack of success in this endeavor, but he is also disgusted by just how obsessed the lieutenant has become with the idea of having another man's wife. When Silva sends Lituma to scout the beach as part of a plan to surprise Adriana alone, Lituma finds the woman and engages her in conversation. He learns of Adriana's love for her husband and the difficulties financial considerations have placed on their relationship. Lituma is, at this point, not "working" for Silva but rather against him. Lituma is a romantic at heart, and prior to informing Adriana of the reason for his presence on the beach, he asks her if

\footnotetext{
${ }^{6}$ See Shaw's comments concerning the difference between sexuality and love. He presents the idea that writers of the "Boom" tended to privilege sexuality and exclude love.
} 
she really loves Matías. She replies that despite obstacles, they have been together for twenty-five years and continues to say:

Mis padres no querían que me casara con él. Decían que era muy viejo, que el matrimonio no duraría. Se equivocaron, ya ves. Ha durado y, con todo, nos hemos llevado bastante bien. ¿Por qué me preguntas si lo quiero?

Lituma poses the question, it seems, because he wants to validate the embarrassment he feels at being there to help arrange Silva's plan. He desperately wants to believe in love and the possibility of its existence in a world that has bitterly disappointed him in terms of fostering true love; he is ashamed to represent Silva's base sexual desires and disregard for the sanctity of the institution of marriage. Lituma enjoys his conversation with Adriana because her description of her love for Matías helps to bolster his sagging faith in true love. He even tells her, "gracias a nuestra charla, me olvidé del flaquito que mataron." (80)

In the end and due to the circumstances of the criminal investigation, however, Lituma is saddened by what he sees and learns. All around him he finds examples of the control that societal corruption and injustice have on the lives of individuals. It is through his portrayal of society's predilection for structure and compliance over love and emotion that Vargas Llosa depicts the oppressive nature of Peruvian society, and it is through Lituma that the reader is made to see the inadequacy of individual effort against collective injustice. Lituma is amazed, indeed encouraged, to learn that Palomino had enlisted in the air force for reasons of love, but Silva quickly cheapens the moment. Lituma asks his Lieutenant:

¿No le parece extraordinario que alguien haga una cosa así? ¿Qué un muchacho, exonerado del servicio, venga y se enrole por amor, para estar junto a la hembrita que quiere?

but Silva replies:

¿¿Y por qué te admira tanto eso? ... no sabes lo que es el amor... Yo me metería de avionero, de soldado raso, de cura, de recogedor de basura y hasta comería caca si hiciera falta, para estar cerca de mi gordita, Lituma.

Both the content of Silva's response and his use of the word "caca" destroy what was a beautiful revelation for Lituma. 
The sadness and disappointment experienced by Lituma as a result of the disturbing details of the investigation are perhaps best summarized in a description of his reaction to learning about Mindreau's incestuous relationship with his daughter:

Sintió pena. Por él, por el Coronel Mindreau, por el flaquito, por la muchacha. Tenía ganas de echarse a llorar de pena por el mundo entero, carajo.

With this, Vargas Llosa clearly expresses his concern that tragically, the confrontation between the individual and society usually results in corruption, injustice and blind adherence to collective "agreement" suppressing beauty, love, and truth.

It is, then, through a combination of two distinct "storylines" that Vargas Llosa creates his narrative portrayal of what he perceives to be ambiguous Peruvian social realities. By countering the criminal investigation, (an investigation that involves love and sex), with a tale of unrequited lust, the author ultimately depicts a society "in which the individual can hardly escape the taint of corruption," (951) as Penuel states, and in which the beauty of love is almost entirely eclipsed by a destructive sexuality. Helen L. Ryan-Ranson says that Vargas Llosa "ha creado un mundo novelístico que es alucinante, enajenado, angustioso, tenso e irreal," y que "ha hecho su denuncia de la corrupción social en el Perú y ha puesto en cuestión los valores morales de la sociedad" (149).

Manuel Quiroga Clérigo summarizes the issue of the tragic implications of social and racial influences and pressures on affairs of the human heart by stating that Vargas Llosa

[h]a derivado todo hacia una acción coordinada de asesinos que tratan de romper un simple corazón, el de Palomino Molero, por haberse entrometido en el cuento de hadas que no le podía pertenecer. ... Así es como surgirá una especie de colectiva corrupción capaz de llegar al asesinato y de provocar la inútil tragedia. (131-34)

Both Palomino Molero and Lituma struggle for confirmation of the possibility of the existence of true love free from social mandates and restrictions, but both are disappointed and ultimately consumed by "la inútil tragedia" that Vargas Llosa so artfully evokes in this novel.

As mentioned earlier, it is not only through his double thematic structure that Vargas Llosa registers sexuality in this novel, but also through the use of a narrative counterpoint that emphatically echoes the 
corrupt, vile, crude, and sexually base nature of the social reality described. Kenneth M. Taggart asserts that Vargas Llosa uses this technique in a number of his works but perhaps never to such great effect as he does in ¿Quién mató a Palomino Molero? (151). Taggart also states:

Es sabido que Vargas Llosa tiene una pasión por el cine y por eso nos parece probable que haya adaptado algunas técnicas de este medio. En muchos episodios hay sonidos (el mar, un diálogo de fondo, maullidos de gato) que el autor dirige y utiliza de la misma manera que el director de cine emplea la música de fondo como contrapunto para complementar o aumentar el tono o tema de la escena.

In ¿Quién mató a Palomino Molero?, sex and sexual noises function as counterpoint to the criminal investigation of Palomino's death. During their interview with doña Lupe, for example, Lituma and Silva hear animal sounds that serve as background noise for their conversation about Palomino and Alicia:

El rebuzno enloquecido de una burra quebró, a lo lejos, la quietud del exterior. "Se la están cachando," pensó Lituma.

Later in the conversation Lituma's thoughts are again drawn to what is happening outside:

El rebuzno obsceno hirió de nuevo la mañana, más cerca, y Lituma oyó también un galope. "Ya se la tiró," dedujo.

This "atmosphere" created by the animals should not be interpreted as interruptions or distractions, however, but rather as counterpoint reflections of the plot. Taggart claims that the noises evoke Lupe's tale about the two lovers:

Cuando doña Lupe revela que les dio cama [a Palomino y Alicia], la evocación de los momentos de intimidad entre los enamorados se refleja contrapuntísticamente por medio del rebuzno.

Another example of this rather coarse sexual imagery is registered later in the novel when the two policemen query Coronel Mindreau about his daughter, Palomino, and Lieutenant Dufó. Once again, the counterpoint contributes to the meaning of the conversation given the context and subject:

A lo lejos, varios gatos maullaban y chillaban, frenéticos: ¿estarían peleándose o cachando? Todo era confuso en el mundo, carajo. 
Given the harm and pain that love and sex caused for Mindreau, Alicia, Palomino, and Dufó, Lituma's confusion about the fine line or distinction between "pelearse y cachar," fighting and making love, seems very justified. Taggart adds that the

maullidos frenéticos sintetizan, de una manera tergiversada, lo acabado de narrar-el amor imposible de los enamorados, el amor no correspondido del teniente Dufó y la pasión prohibida del padre.

This sexual counterpoint emphasizes an important aspect of the main theme of the novel: the individual finds it difficult to battle against collective corruption and social injustice because his passion, the emotion that drives sexuality and love, isolates and alienates him. Penuel states that the emotions that revolve around sex and love in ¿Quién mató a Palomino Molero? have passion as a common denominator and that this passion "both unites and divides characters. The common source of their best and worst conduct, passion is the basis for their self-fulfillment, destruction of others, and self-destruction" (946). ${ }^{7}$ The reader sees sex and love in only a negative or "ugly" light in this novel. Sexual love, filtered through the injustice of society's restrictions, brings about the destruction of many characters. Through counterpoint, sex is reduced to the obscene noises made by mating animals. Coronel Mindreau's comment that "hay un fondo bestial, en todos. Cultos o incultos, todos" (159), is particularly illuminating in this context as it helps define how passion is to be perceived in the novel: as a base emotion capable of magnificent or catastrophic results; the compassion Lituma has for Palomino, or the latter's revolting murder.

An additional aspect of this counterpoint in the novel is the use of sexually oriented profanity. Lieutenant Silva, for example, scarcely utters a line without swearing or referring to sex. It is not necessary to exhaustively enumerate examples of profanity in the narrative, but a few examples serve to demonstrate how this type of language contributes to the author's statement about society's lurid nature and the individual's reaction to injustice.

With frequent use of such words as "puta," "concha de su madre,"

${ }^{7}$ Penuel goes on to state that the novel "provides a rich psycho-social vision of humanity in which passion, the fundamental determinant of the characters' lives, flows into various channels, according to their psychological predispositions and social circumstances" (946). 
"chucha," "huevón," etc., ${ }^{8}$ lieutenant Silva swears often. This language seems to come to him naturally and it almost defines or punctuates his speech. He uses profanity to make his points, feeling that this language accords proper emphasis to important issues. In conversation with doña Lupe, Silva says:

Si usted no coopera, si no responde a mis preguntas, se va a meter en un lío de la puta madre. Se lo digo así, con palabrotas, para que se dé cuenta de lo grave que es.

Another "offender" in this area is Richard Dufó, whose crude and obnoxious behavior during his drunken tirades is peppered with profanity. While being interrogated by Silva and Lituma, Dufó asks the former, "¿Quién chucha eres tú y quién chucha es tu madre?" and later says "Tú debes ser maricón ... ¿me has traído aquí para que te haga el favor de meterte la pichula?" (64) These are only a few examples of the drunk airman's language, but it is apparent that he, like Silva, relies on sexual profanity to convey his reactions, impressions and opinions.

Nana Badenberg, Alexander Honold, and Susan Horstmann offer insightful analysis on the use of profanity in general and specifically on its use in the novel:

Aquí se podría adelantar tal vez la hipótesis de que existiría una relación de correspondencia entre una lengua vulgar y una situación de fracaso, inseguridad o ausencia de poder.

This interpretation of the importance of vulgar language in the novel seems quite appropriate given the book's general theme. Almost all the characters use profanity, (except for Mindreau, a man who at least nominally controls his social circumstances and position of power), and all find themselves in some position of weakness. This language, a dominant characteristic of the novel, reflects the plight of the individual in society and his struggle

\footnotetext{
${ }^{8}$ See Badenberg et al. The authors give a detailed account; of the profanity found in the novel.
} 
against collective societal forces that unjustly deprive him of love, dignity, and happiness. ${ }^{9}$

Considered in its entirety, ¿Quién mató a Palomino Molero? is a masterful novelistic presentation of Vargas Llosa's perception of inequities and power in Peruvian society. Individual characters are found to be sadly inadequate and powerless when faced with collective corruption and apparent intrinsic moral and ethical bankruptcy. By employing a sexual counterpoint as a narrative strategy to augment the principal thematic issue of "the search for truth," the author emphasizes a certain bestial nature in mankind that results in social isolation if not self-destruction. As Mindreau states in his confession to Silva and Lituma, "hay un fondo bestial, en todos. Supongo que más en las clases bajas, entre los cholos. Resentimientos, complejos" (159). That "fondo bestial," manifested through love and sex in the novel, eventually effects Mindreau's own destruction and the exposure of social injustice seen through Vargas Llosa's eyes. The only adequate or appropriate response to this reality seems to be the expression that both begins and ends the novel: Lituma's "jijunagrandísimas."

\section{WORKS CITED}

Badenberg, Nana, Alexander Honold, and Susanne Horstmann. "¿Quién mató a Palomino Molero?: Vargas Llosa y la novela policial." Revista de Crítica Literaria Latinoamericana 15 (1989): 277-316.

Béjar, Eduardo. "La fuga erótica de Mario Vargas Llosa." Symposium 46:4 634-42.

Gerdes, Dick. Mario Vargas Llosa. Boston: Twayne, 1985.

Ortega, Julio. "García Márquez y Vargas Llosa, imitados." Revista Iberoamericana 52 (1986): 971-78.

Penuel, Arnold M. "The Uses of Literary Perspectivism in Vargas Llosa's ¿Quién mató a Palomino Molero?." Hispania $73.4943-$ 52.

${ }^{9}$ See Béjar for an interesting interpretation of Adriana's use of profanity and the consequent destruction of Silva's manhood. The author states that Adriana's appropriation of whorehouse slang undercuts Silva's authority and leads to the latter's failure to realize his goal of raping the woman (246). Here again, profanity is used by the powerless in response to a threat or statement by the powerful. 
Quiroga Clérigo, Manuel. "Vargas Llosa: drama y tragedia." Cuadernos Hispanoamericanos 438: 131-34.

Ryan-Ranson, Helen L. "Lo grotesco en ¿̇Quién mató a Palomino Molero?." Mario Vargas Llosa: Opera Omnia. Ana María Hernández de López, ed. Madrid: Pliegos, 1994. 139-50.

Shaw, Donald L. "Love and Sex in Skármeta's Match Ball." Love, Sex \& Eroticism in Contemporary Latin American Literature. Alun Kenwood, ed. Melbourne: Voz Hispánica, 1992. 23-34.

Taggart, Kenneth M. "La técnica del contrapunto en ¿Quién mató a Palomino Molero?." Mario Vargas Llosa: Opera Omnia. Ana María Hernández de López, ed. Madrid: Pliegos, 1994. 151-58.

Vargas Llosa, Mario. ¿Quién mató a Palomino Molero?. Barcelona: Seix Barral, 1986. 
Copyright of Hispanic Review is the property of Hispanic Review and its content may not be copied or emailed to multiple sites or posted to a listserv without the copyright holder's express written permission. However, users may print, download, or email articles for individual use. 